\title{
THE IMPACT OF ACIDIC ORGANIC MATTER ON THE DIVERSITY OF UNDERWATER VEGETATION IN SOFT WATER LAKES
}

\author{
KATARZYNA BOCIĄG \\ Department of Plant Ecology, University of Gdansk \\ Al. Legionów 9, 80-441 Gdansk, Poland \\ e-mail: dokkb@univ.gda.pl
}

(Received: October 31, 2002. Accepted: June 13, 2003)

\begin{abstract}
This paper addresses underwater vegetation in soft water lakes which are influenced by the anthropogenic input of allochtonic dissolved organic matter (DOM) from drained bogs. The aim of this work is to test the hypothesis regarding the role of DOM in shaping the diversity of underwater vegetation. Large differences in underwater vegetation habitats, the limitation of their occurrence to increasingly shallower littoral (the depth of the lower limit of their occurrence decreased from $12 \mathrm{~m}$ up to $1 \mathrm{~m}$ ) and the regression of underwater vegetation were observed in lake types ranging from oligohumic (median $(\mathrm{Me})$ of DOC in water $=2.5 \mathrm{mg} \mathrm{C} \mathrm{dm}^{-3}$ ) to polyhumic $(\mathrm{Me}$ of DOC $=35.6 \mathrm{mg} \mathrm{C} \mathrm{dm}^{-3}$ ). The gradual simplification of internal plant patch structure occurred and the Shannon-Weaver diversity index decreased (Me $0.04 \rightarrow 0.00)$. Fewer species were observed in the lakes $(\mathrm{Me} 9 \rightarrow 2$ ), and the underwater vegetation covered increasingly smaller areas. Species replacement did not occur and no invasive species appeared.
\end{abstract}

KEY WORDS: humic substances, dissolved organic matter (DOM), underwater vegetation, diversity, Shannon-Weaver index.

\section{INTRODUCTION}

One of the significant causes of changes in contemporary water vegetation is human activity. The anthropogenic factor often causes vegetation regression, which frequently indicates a disaster in the natural environment. One of the activities, which has an adverse impact, is the draining of swamps and peat bogs, as these waters deposit large amounts of foreign organic matter, including humic substances (HS), into lakes. The chemical and physical results of the anthropogenic enrichment of lakes with allochtonic acidic organic matter is known as humication (Szmeja 2000; Bociąg and Szmeja 2001). To date, many lakes which have undergone humication are regarded as natural dystrophic lakes.

Dissolved organic matter (DOM) from swamps and bogs is mainly composed of humic substances (HS; Thurman 1985). HS are bio-polymers that are created during the humication process of organic matter. They have a specific structure and properties (Aiken et al. 1985). Progress in the study of the structure, genesis and role of DOM, including HS, in lake ecosystems (Hessen and Tranvik 1998; Keskitalo and Eloranta 1999) has created a solid foundation for undertaking specific phytoecological studies.

Variations of the chemical and physical features of the lakes and macrophyte habitat due to humication have been preliminarily identified (Szmeja et al. 2001; Banaś 2002).
It is known that humication usually distorts the developmental course of lakes, and processes within the underwater vegetation community are modified significantly (Szmeja 2000). This paper, which addresses vegetation diversity, presents a portion of the results of the author's studies on changes in underwater vegetation during humication in soft water lakes.

The aim of the work is to test the hypotheses regarding the role of DOM in shaping settlements and the diversity of underwater vegetation by comparing the vegetation in groups of lakes with various DOM concentration. The following hypotheses were verified:

1. Allochtonic organic matter modifies underwater plant habitats (location in the depth gradient, sediment and water features).

2. Habitat transformation causes a decrease in underwater vegetation diversity at different levels of their organization.

\section{METHODS}

The studies were carried out each July from 1996 to 2001 in northwestern Poland. Two groups of soft water lakes were studied. The first one included 12 oligohumic lakes, which had neither an inflow of allochtonic DOM nor 
a significant contribution from surrounding peat bogs and the DOC concentration in their water was $<4.0 \mathrm{mg} \mathrm{C} \mathrm{dm}^{-3}$. The second group included 16 humic lakes that received water from peat bogs through drainage canals. This group was divided into three categories according to Szmeja (2000) as follows: $\alpha$-mesohumic lakes (water DOC concentration 4.1-8.0 $\mathrm{mg} \mathrm{C} \mathrm{dm}^{-3}$ ), $\beta$-mesohumic (8.1-16.0 mg $\left.\mathrm{C} \mathrm{dm}^{-3}\right)$, polyhumic lakes $\left(>16.0 \mathrm{mg} \mathrm{C} \mathrm{dm}^{-3}\right)$.

The studied lakes are located in the Pomeranian region of northwestern Poland in a landscape of terminal and ground moraines and on outwashes. Their drainage areas are forests and forest-agricultural lands. Excluding humication, these lakes are not subject to significant anthropogenic pressure. The majority of them are smaller than 20 ha with depths reaching $20 \mathrm{~m}$. All of the lakes are poor in calcium and carbonates $\left(\mathrm{Ca}-\mathrm{Me}=3.6\right.$, range $1.4-11.2 \mathrm{mg} \mathrm{dm}^{-3}$, hardness $-\mathrm{Me}=7.1$, range $2.5-19.7 \mathrm{mg} \mathrm{CaO} \mathrm{dm}^{-3}$ ), and are oligo- and mesotrophic (phosphorus content in water$\mathrm{Me}=0.11$, range $0.07-0.32 \mathrm{mg} \mathrm{dm}^{-3}$ ).

The physical and chemical properties of the water and the sediments near the underwater vegetation habitats were determined in all the lakes, as was the diversity of vegetation. Studies of the vegetation were carried out once in each lake, and only the underwater macrophytes were taken into account (Cormophyta, Bryophyta and Characeae). A study area $50 \mathrm{~m}$ in length was designated in each lake; the width of this area depended on the maximum depth at which vegetation occurred. Each study area was divided into $1 \mathrm{~m}$ depth zones. In these zones plant samples were collected (while diving) from 10 plots of $0.1 \mathrm{~m}^{2}$ at $2.5 \mathrm{~m}$ intervals. A total of 2050 samples were collected. The samples were sorted by species, dried at $95^{\circ} \mathrm{C}$ and then weighed. The number of species in a lake was determined on the basis of detailed floristic examinations.

The changes which took place in the vegetation during humication were studied at two organization levels - wi- thin the plant patches (i.e. alpha-diversity, according to Whittaker 1967 and 1975) and on the littoral scale. Diversity within the patches was evaluated using individual samples $\left(0.1 \mathrm{~m}^{2}\right)$, and the littoral vegetation diversity was evaluated for the entire study area. The number of species was considered $\left(\mathrm{N}_{\mathrm{P}}, \mathrm{N}_{\mathrm{L}}\right.$, respectively) as were the ShannonWeaver index $\left(\mathrm{H}_{P}, \mathrm{H}_{\mathrm{L}}\right)$ and the evenness index $\left(\mathrm{I}_{\mathrm{P}}, \mathrm{I}_{\mathrm{L}}\right)$. $\mathrm{H}$ was calculated from the following formula (Shannon and Weaver 1949; Huston 1996):

$\mathrm{H}=-\Sigma\left[\left(\mathrm{m}_{\mathrm{j}} / \mathrm{m}\right) \times \log \mathrm{m}_{\mathrm{j}} / \mathrm{m}\right]$, where: $\mathrm{m}_{\mathrm{j}}-$ species biomass ,j” [g d.w.], $\mathrm{m}$ - total biomass [g d.w.]. The index I was calculated using the Pielou formula (1966): I = H/H max., where: $\mathrm{H}$ - Shannon-Weaver index, $\mathrm{H}$ max. - maximum value of this index for $\mathrm{n}$ species, i.e. $\mathrm{H} \max .=\log \mathrm{n}$. The plant frequency was calculated using the following formula: $\mathrm{F}=\mathrm{n}_{\mathrm{S}} / 10 \times \mathrm{n}_{\mathrm{Z}}$, where: $\mathrm{n}_{\mathrm{S}}-$ number of plant samples in a zone; $\mathrm{n}_{\mathrm{Z}}$ - number of zones per study area.

Samples of surface water, the water directly above the sediments and the sediments $(0-10 \mathrm{~cm}$ layer $)$, were collected once in order to evaluate habitat changes. The water from directly above the sediments and the sediment samples were collected by divers in the littoral at depth increments of $1 \mathrm{~m}$. Surface water samples were used to determine coloration and DOC. The coloration was determined by using the comparative method according to the platinumcobalt scale. The DOC concentration, which indicates DOM content, was determine spectrophotometrically, according to Moore 1987, by $\lambda=260$ and $330 \mathrm{~nm}$. Secchi disc visibility was also determined. The $\mathrm{pH}$, conductivity, calcium concentration (by titration), total nitrogen and phosphorus content (spectrophotometrically according to Clesceri et al. 1989) were determined for the samples of water from directly above the sediments. The conductivity, $\mathrm{pH}$, redox potential, calcium content, phosphorus and total nitrogen were determined for the sediment samples using the same methods as applied to the water samples. Additional-

TABLE 1. Features of habitats in oligo-, meso- and polyhumic lakes.

$\mathrm{n}$ - number of samples, $\mathrm{X} \pm \mathrm{sd}$ - arithmetic mean \pm standard deviation, Me - median mean, * statistically significant differences $\alpha=0.05$ (tested ANOVA Kruskal-Wallis)

\begin{tabular}{|c|c|c|c|c|c|c|c|c|c|}
\hline \multirow{2}{*}{$\begin{array}{l}\text { Habitats } \\
\text { Feature }\end{array}$} & \multicolumn{4}{|c|}{ Oligohumic } & \multicolumn{5}{|c|}{ Meso- and Polyhumic } \\
\hline & $\mathrm{n}$ & $X \pm s d$ & $\mathrm{Me}$ & min.-max. & $\mathrm{n}$ & $X \pm s d$ & $\mathrm{Me}$ & $\min .-\max$. & \\
\hline WATER & & & & & & & & & \\
\hline Color [mg Pt dm $\left.{ }^{-3}\right]$ & 12 & $5.0 \pm 4.8$ & 4.5 & $0-17$ & 13 & $125 \pm 161$ & 60 & $13-600$ & * \\
\hline $\mathrm{DOC}\left[\mathrm{mg} \mathrm{C} \mathrm{dm}^{-3}\right]$ & 12 & $2.9 \pm 1.25$ & 2.5 & $1.8-3.9$ & 13 & $13.5 \pm 12.5$ & 8.5 & $4.7-44.0$ & $*$ \\
\hline $\mathrm{pH}$ & 115 & $5.5 \pm 1.0$ & 5.3 & $4-7.5$ & 42 & $5.4 \pm 1.1$ & 4.5 & $4.2-7.6$ & \\
\hline $\mathrm{Ca}\left[\mathrm{mg} \mathrm{dm}^{-3}\right]$ & 115 & $4.0 \pm 2.9$ & 3.5 & $1.3-11.6$ & 42 & $4.2 \pm 2.6$ & 3.0 & $1.2-11.5$ & \\
\hline $\mathrm{P}_{\text {tot }}\left[\mathrm{mg} \mathrm{dm}^{-3}\right]$ & 115 & $0.11 \pm 0.04$ & 0.10 & $0.06-0.23$ & 42 & $0.13 \pm 0.12$ & 0.10 & $0.07-0.90$ & \\
\hline $\mathrm{N}_{\text {tot }}\left[\mathrm{mg} \mathrm{dm}^{-3}\right]$ & 115 & $1.22 \pm 0.49$ & 1.13 & $0.46-3.0$ & 42 & $2.7 \pm 1.4$ & 2.5 & 0.87-6.04 & $*$ \\
\hline SEDIMENT & & & & & & & & & \\
\hline $\mathrm{pH}$ & 115 & $5.9 \pm 0.5$ & 5.9 & $4.4-6.9$ & 42 & $5.8 \pm 0.5$ & 5.8 & $4.5-6.9$ & \\
\hline$\chi\left[\mu \mathrm{S} \mathrm{cm}^{-1}\right]$ & 115 & $60.3 \pm 34.9$ & 54 & $12-178$ & 42 & $51.0 \pm 25.0$ & 50.75 & $12.5-112.7$ & \\
\hline Potential [mV] & 115 & $-116 \pm 174$ & -175 & $-340-358$ & 42 & $-159 \pm 163$ & -213 & $-337-354$ & \\
\hline $\mathrm{P}_{\text {tot }}\left[\mathrm{mg} \mathrm{g} \mathrm{d.w.} .^{-1}\right]$ & 115 & $3.79 \pm 7.59$ & 0.28 & $0.03-38.79$ & 42 & $3.34 \pm 6.4$ & 0.27 & $0.06-26.4$ & \\
\hline $\mathrm{N}_{\text {tot }}[\mathrm{mg} \mathrm{g} \mathrm{d.w.-1}]$ & 115 & $10.4 \pm 8.3$ & 6.7 & $1.6-32.5$ & 42 & $14.8 \pm 12.7$ & 8.38 & $3.4-44.5$ & $*$ \\
\hline $\mathrm{HS}$ [mg g d.w. $\left.{ }^{-1}\right]$ & 115 & $38.0 \pm 34.6$ & 26.8 & $1.9-138.7$ & 42 & $43.2 \pm 46.2$ & 28.1 & $1.8-155.8$ & \\
\hline Hydration [\%] & 115 & $52.8 \pm 27.6$ & 48 & $14-95$ & 42 & $48.1 \pm 29.9$ & 33.5 & $15-94$ & \\
\hline Organic matter [\%] & 115 & $30.3 \pm 28.5$ & 20.3 & $0.2-90.2$ & 42 & $19.1 \pm 23.2$ & 4.6 & $0.21-75.7$ & $*$ \\
\hline Depth of the lower limit [m] & 12 & $9.6 \pm 2.1$ & 9.5 & $6-12$ & 13 & $3.3 \pm 1.7$ & 3 & $0.5-6$ & $*$ \\
\hline
\end{tabular}


ly, the hydration, organic matter content and the humic acid concentrations (using extraction and the determination of oxidable OC following the modified method of Tiurin according to Górniak 1996) were also determined.

The essential hypothesis regarding the significance of the differences between these features was verified using the ANOVA variance analysis method. In cases when the assumptions were not confirmed, the nonparametric KruskalWallis test (for $p=0.05$; Kruskal and Wallis 1952) was applied. The specifics of the habitats were analyzed with principle component analysis (PCA) with Varimax rotation (Lindeman et al. 1980).

\section{RESULTS}

\section{Habitat transformation}

The oligohumic lakes, their drainage areas and hydrological systems were highly natural. The majority of them did not have outlets and were astatic. The fundamental characteristic of the underwater plant habitats in these lakes was the low content of DOM in the water. This meant that the water was almost colourless, the littoral was well illuminated and the underwater vegetation habitats reached depths of down to $12 \mathrm{~m}$ (Table 1, Fig. 1). They had a wide $\mathrm{pH}$ range in the layer close to the sediments $(\mathrm{pH} 4.0-7.5 ; \mathrm{Me}=$ 5.3 ), their conductivity was low and the calcium content was very low (in water $1.3-11.6 \mathrm{mg} \mathrm{dm}^{-3}$; $\mathrm{Me}=3.5$ ). Principal Components Analysis indicated that $\mathrm{Ca}$ concentration, water $\mathrm{pH}$ and water and sediment conductivity were the principle factors contributing to the variability of the oligohumic habitats (explained $27.5 \%$ of the variances). Changes in the sediments (hydration, organic matter content, HS, $\mathrm{N}_{\text {tot }}$ and $\mathrm{P}_{\text {tot }}$ ) along the depth gradient were equally important (24\% variances). The shallow parts of the habitats up to $3 \mathrm{~m}$ deep were strongly eroded by waves and the soil was mineral, badly hydrated and poor in HS. At depths greater than $3 \mathrm{~m}$, the bottom was covered by accumulation sediment. As a result, the sediment was more hydrated and richer in organic substances, including humic substances.

The meso- and polyhumic lakes had distorted hydrologic systems in the drainage areas and they were altered by the inflow of allochtonic DOM from various types of peat bogs. The underwater vegetation habitats of meso- and polyhumic lakes differed primarily from those in oligohumic lakes in that there were higher concentrations of DOM in their waters. As a result, the water color was more distinct $(\mathrm{p}<0.001)$, visibility was worse $(\mathrm{p}<0.001)$ and the total nitrogen content was higher $(\mathrm{p}=0.01)$. The habitats in the meso- and polyhumic lakes were much narrower and were mainly located in the erosion zone where the soil was less hydrated $(\mathrm{p}=0.04)$ and contained less organic matter $(\mathrm{p}=$ 0.01). Despite this, the main factor which explained their variability were the characteristics of the sediments which diverge sharply at the border of the erosion and accumulation zones (hydration, organic matter content, $\mathrm{HS}, \mathrm{N}_{\text {tot }}$ and $\mathrm{P}_{\text {tot }} ; 30 \%$ of total variance). The smaller impact was related to the aggregate stock of carbonates in the habitats (21\% of total variance). In comparison with oligohumic habitats, the conductivity of the water close to the sediments was higher $(p=0.02)$, while the calcium content in the sediments was lower $(\mathrm{p}=0.01)$ and that of nitrogen was higher $(\mathrm{p}=$ 0.03 ; Table 1)
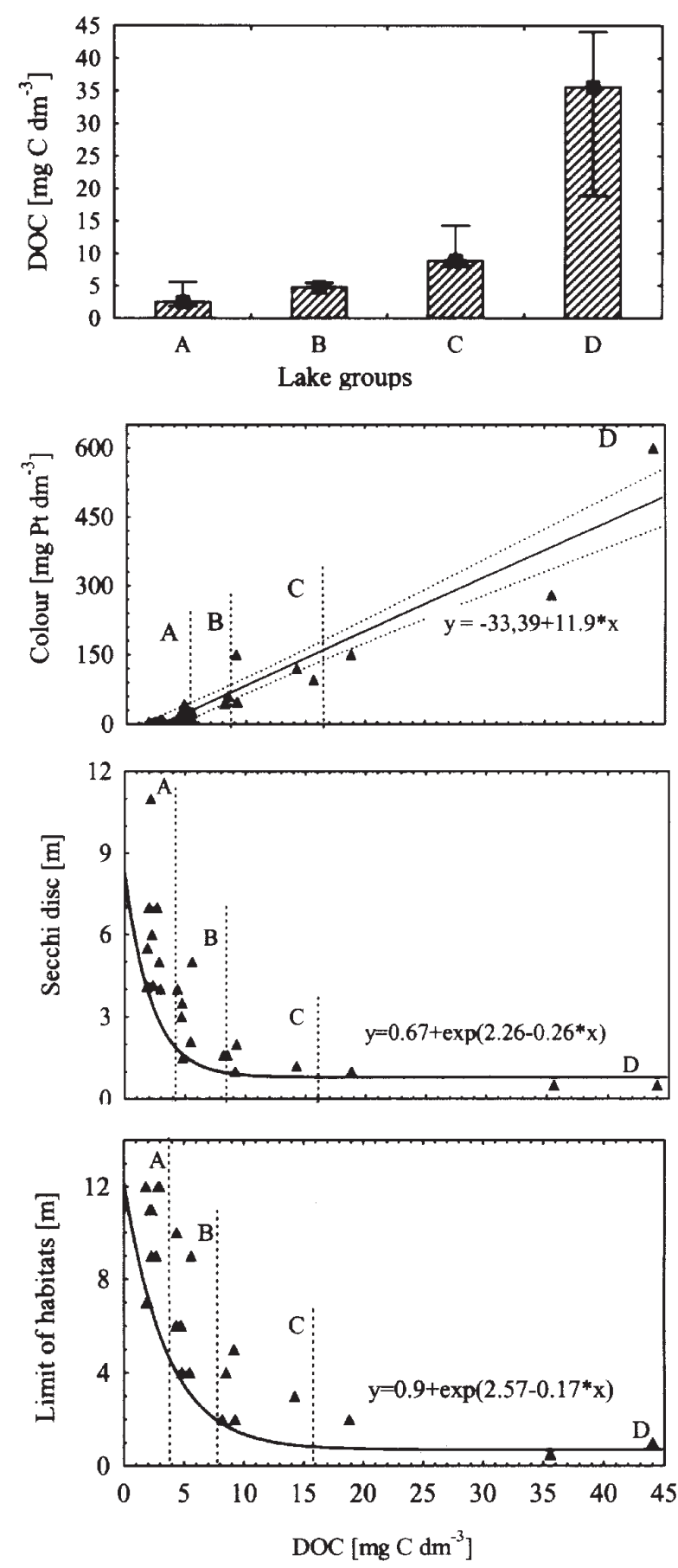

Fig. 1. Features of underwater vegetation habitats in oligo- (A), $\alpha$-meso(B), $\beta$-meso- (C) and polyhumic (D) lakes. $\square$-median mean, I - range.

The habitats in $\alpha$-mesohumic lakes were located at shallower depths than those in oligohumic lakes (Fig. 1). In the surface waters of the former, the DOC concentration was, on average, two times higher than that in oligohumic lakes ( $\mathrm{Me}=4.8$ versus $\left.\mathrm{Me}=2.5 \mathrm{mg} \mathrm{C} \mathrm{dm}^{-3}, \mathrm{p}=0.01\right)$. Visibility in these lakes was almost two times lower than in oligohumic lakes and the water was much darker (13-43, Me = 21.5 versus $0-17, \mathrm{Me}=4.5 \mathrm{mg} \mathrm{Pt} \mathrm{dm}^{-3}, \mathrm{p}=0.03$ ). The conductivity of the water was slightly higher than that in oligohumic lakes, as were the calcium and nitrogen concentrations $(p<0.01)$. The sediments contained less calcium than in oligohumic habitats $(\mathrm{p}<0.01)$, and it was more mineral and less hydrated (Fig. 1). 


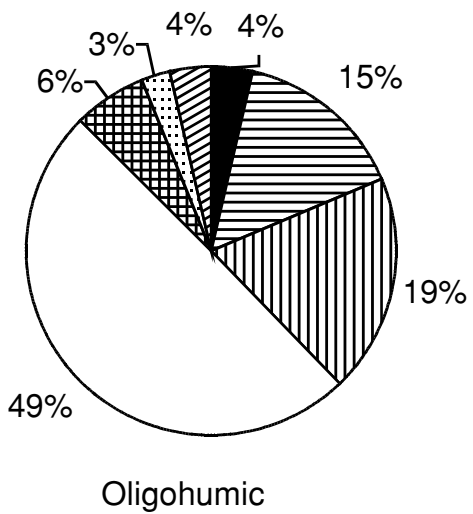

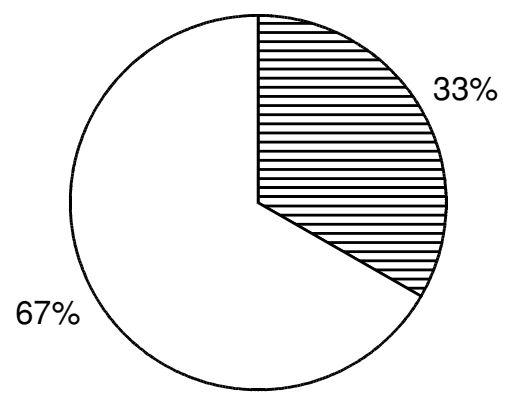

Polyhumic lakes
Species groups combination in the patches

Bryophyta, Characeae and Cormophyta 目 Cormophyta

II Bryophyta and Cormophyta

Bryophyta

囲 Bryophyta and Characeae

Characeae

Characeae and Cormophyta

Fig. 2. Structure of plant patches in oligohumic and polyhumic lakes. $\%$ - share of patches with definite species groups combination

The $\beta$-mesohumic habitats were located mainly in the shallow littoral (Fig. 1). Due to the greater amount of DOM, the water was more strongly colored (44-150 mg Pt $\left.\mathrm{dm}^{-3}, \mathrm{Me}=68 ; \mathrm{p}=0.01\right)$, less transparent $(\mathrm{p}=0.05)$ and were richer in nitrogen $(\mathrm{Me}=3.39$ versus $\mathrm{Me}=2.01 \mathrm{mg}$ $\mathrm{N} \mathrm{dm}^{-3}$ for $\alpha$-mesohumic habitats, $\left.\mathrm{p}<0.01\right)$. Plants grew here under insufficient light conditions and on mineral or mineral-organic soil which was slightly less hydrated (Fig. 1).

Polyhumic habitats were present only in the shallowest and most strongly eroded littoral $(<1 \mathrm{~m})$. The water in these lakes was brownish, sometimes even pitch-black (150$\left.600 \mathrm{mg} \mathrm{Pt} \mathrm{dm}{ }^{-3}\right)$ and visibility was very limited (0.5-1 m). This was mainly the result of high DOM content (the DOC concentration ranges from 18.8 to $44.0 \mathrm{mg} \mathrm{C} \mathrm{dm}^{-3}, \mathrm{Me}=$ 35.6). Plants in these lakes, similarly to that in $\beta$-mesohumic lakes, grew on mineral soil which was strongly eroded by waves (Fig. 1).

In the lakes ranging from oligohumic to polyhumic the inflow of large amounts of DOM into lakes caused an increase in water color. The water color is strongly correlated with the content of DOC $(r=0.95)$. Colorful HS that constitute DOM limited the illumination of plant habitats and reduced the depths at which plants occur (Fig. 1). DOM have an impact on underwater plant habitats not only by reducing illumination. In the sediments of the studied mesoand polyhumic lakes, the phosphorus content decreased as did calcium but to a lesser extent (Table 1). The sediments became also gelatinous, more hydrated and dissolved. Therefore, the sedimentation of DOM modified the sediments and limited the illumination of the habitats. When this occurred, the underwater plant habitats shrank and moved towards the shore (Fig. 1, Table 1). These areas were highly disturbed by waves and their sediments were usually mineral and not very hydrated (Fig. 1, Table 1). Therefore, the transformation of the habitats was caused by the direct impact of DOM and from the indirect impact of their shifting towards the shore.

\section{Diversity of underwater vegetation within patches}

The most common component of the vegetation in oligohumic lakes were Bryophyta (about 60\% frequency), for example Fontinalis antipyretica Hedw., Sphagnum denticulatum Brid., Warnstorfia exanulata (B., S. \& G.) Loeske and Drepanocladus tenuinervis T. Kop. Of the Cormophyta (33\% frequency), isoetids dominated - Isoëtes lacustris L., Lobelia dortmanna L., Littorella uniflora Aschers. The number of species per $0.1 \mathrm{~m}^{2}$ varied from 1 to 7 ; however, in nearly every second sample only one was found and in more than $50 \%$ of the samples there were two at the most. This was due to the fact that half of the patches were created by Bryophyta, which often formed single-species aggregations. Less patches were formed exclusively by Cormophyta, and the least of all patches were created by Characeae. Patches formed by Bryophyta and Cormophyta were relatively common (19\%); Bryophyta with Characeae (6\%) were less common and the least common were patches composed of Cormophyta, Bryophyta and Characeae (a total of 4\%; Fig. 2). The low diversity within the patches was confirmed by the low Shannon-Weaver index $\left(\mathrm{H}_{\mathrm{p}}\right.$; Me $=0.04$, Fig. 3). The $\mathrm{H}_{\mathrm{P}}$ distribution is right-skewed $(\mathrm{Sk}=$
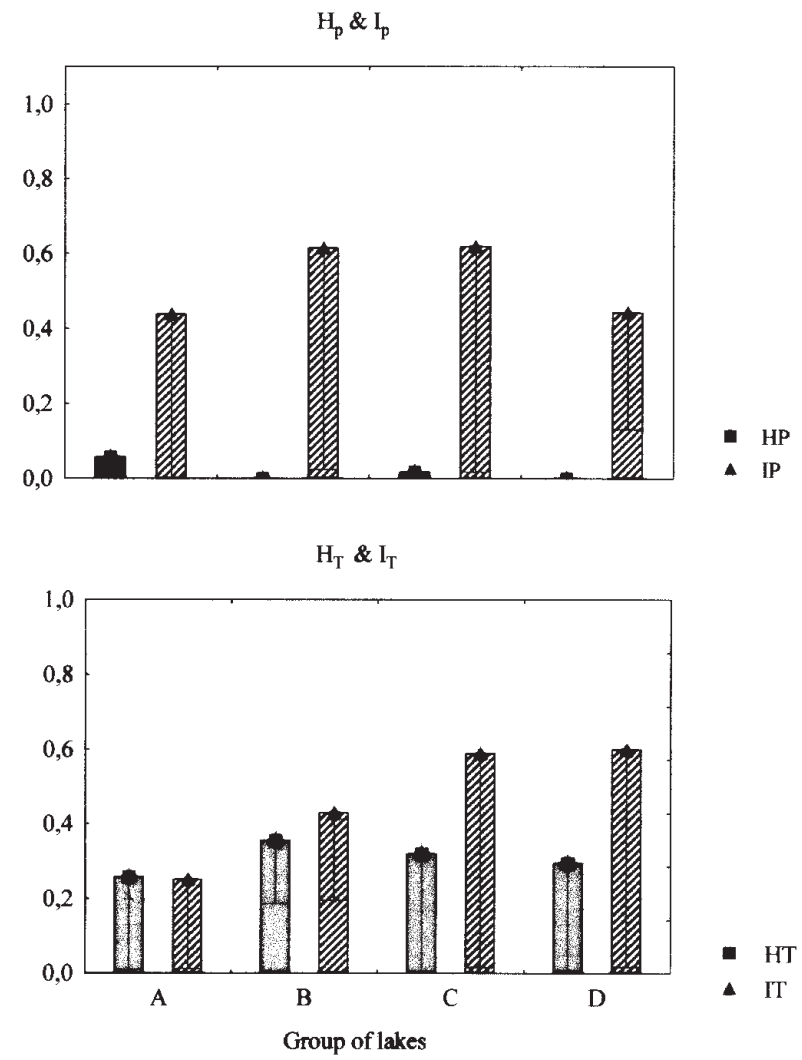

Fig. 3. Shannon-Weaver index and Pielou index (medians) of plant patches $\left(\mathrm{H}_{\mathrm{P}}, \mathrm{I}_{\mathrm{P}}\right)$ and vegetation on the littoral scale $\left(\mathrm{H}_{\mathrm{L}}, \mathrm{I}_{\mathrm{L}}\right)$ in oligo- to polyhumic lakes. Lakes: A - oligo-, $\mathrm{B}-\alpha$-meso-, $\mathrm{C}-\beta$-meso-, $\mathrm{D}$ - polyhumic. 
$1.01)$, and only $4 \%$ of the samples were highly diverse $\left(\mathrm{H}_{\mathrm{P}}>0.4\right)$. The wide range of the index values (0-0.74) indicated that there were large differences between the patches.

Fewer species (1-5) were observed in samples from the $\alpha$-mesohumic lakes and the patch structure was simpler than that in oligohumic lakes. Patches composed of no more than two species dominated. The most common Bryophyta were Sphagnum denticulatum and Warnstorfia exanulata, and the most common Cormophyta were isoetids, as was the case in the oligohumic lakes. However, Cormophyta, Bryophyta and Characeae did not form common patches as they did in oligohumic lakes. The majority of the patches were composed of either Cormophyta or Bryophyta, or, less frequently, of a combination of the two $(13 \%)$, but there was almost a total lack of Characeae. The $\mathrm{H}_{\mathrm{P}}$ median ( $\mathrm{Me}=0.03$; Fig. 2) and variability were similar to that in the oligohumic lakes; however, there are more vegetation patches of higher diversity in these lakes. The evenness index was slightly higher than in oligohumic lakes (Fig. 2). These changes resulted from a reduction in the density of the dominant population, mainly Bryophyta, so that the contribution of species biomass to the total biomass was more uniform in part of the patches.

The patch structure in $\beta$-mesohumic lakes was even simpler than in $\alpha$-mesohumic lakes. Their species composition was similar to the previous group of lakes; patches composed exclusively of either Cormophyta or Bryophyta were common, while patches composed of both Bryophyta and Cormophyta were less numerous. Almost $75 \%$ of the patches consisted of no more than two species and almost half of them contained only one. The $\mathrm{H}_{\mathrm{P}}$ index was lower than in the $\alpha$-mesohumic lakes (Fig. 3).

In polyhumic lakes underwater vegetation appears in very few small, scattered patches composed of mainly one species. The majority of the patches consisted of moss (Fig. 2). The most common species was Fontinalis antipyretica, which tolerates shade and grows in the coastal zone on underwater stones and tree roots.

In lakes ranging from oligohumic to polyhumic, the gradual elimination of plant patches and the simplification of their structure occur. The number of species which form the aggregations decreases, and results in a fall in the Shannon-Weaver diversity index. Due to the prevalence of small, scattered, single-species aggregations, patch diversity in polyhumic lakes is the lowest (Fig. 2, 3).

\section{Diversity of vegetation in the littoral}

Thirty-three underwater plant species were confirmed in the oligohumic lake group, and in the various lakes their number varied from 4 to $16, \mathrm{Me}=9$ (Fig. 4). Cormophyta, mainly isoetids, and Bryophyta occurred in each lake and were represented by 14 and 16 species, respectively. Characeae were less numerous than Cormophyta and Bryophyta and were represented by only three species - Chara delicatula Ag., Nitella opaca Agardh and N. flexilis (L.) Agardh (Table 2). The plants grew mostly to a depth of $9.6 \mathrm{~m}$ in the littoral. Their frequency was high and reached almost $90 \%$. Diversity on the littoral scale, expressed by the $\mathrm{H}_{\mathrm{L}}$ index, had a wide range (0.01-0.6; $\mathrm{Me}=0.26$, Fig. 3) which was similar to the diversity within the patches. A low $\mathrm{H}_{\mathrm{L}}$ value $(<0.2)$ was characteristic of vegetation in lakes with very acidic waters $(\mathrm{pH}<5.5)$. These lakes usually supported very few species, from 4 to 9 , with one of them, for example

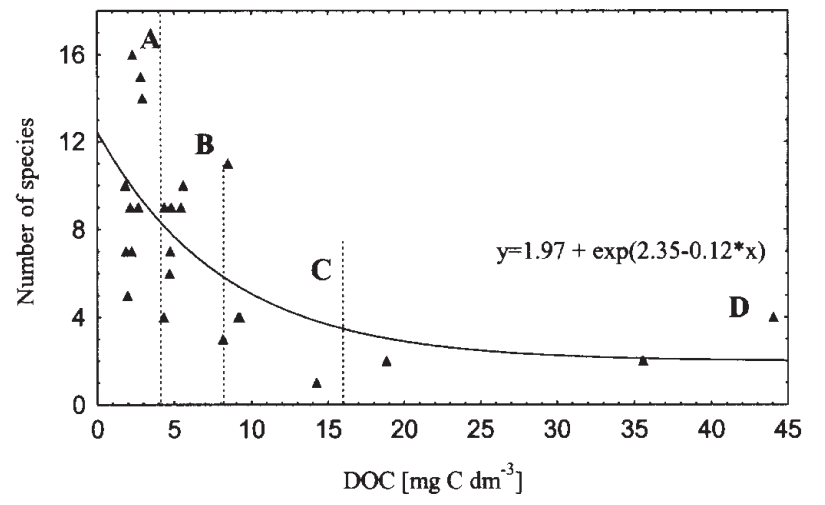

Fig. 4. Dependence of the number of species on the DOC concentration in oligo- to polyhumic lakes. Lakes: A - oligo-, B - $\alpha$-meso-, $\mathrm{C}-\beta$-meso-, $\mathrm{D}$ - polyhumic.

Sphagnum denticulatum, as the dominant species. The vegetation diversity was higher $\left(\mathrm{H}_{\mathrm{L}}>0.2\right)$ in lakes that had higher values of water $\mathrm{pH}(\mathrm{pH}>5.5)$ and more abundant carbonates; this was related to the greater number of species (9-16), several of which can co-dominate.

Twenty species occurred in the $\alpha$-mesohumic lakes; this figure was far lower than that in the oligohumic lakes (33). Similarly to the oligohumic lakes, the majority of these species were Bryophyta and Cormophyta. The dissimilarity of flora in the $\alpha$-mesohumic lakes was very low with just two new species (Table 2). Plants grew in much shallower areas (on average to $5 \mathrm{~m}$ ) and the plant patches covered, on average, $60 \%$ of the littoral area. Despite the occurrence of fewer species, the $\mathrm{H}_{\mathrm{L}}$ index was higher than in oligohumic lakes ( $\mathrm{Me}=0.35$, Fig. 2) and its range was narrower (0.19$0.64)$. This means that domination of one species in $\alpha$-mesohumic lakes was not as strong since the appearance of even a small amount of DOM in the lake initially leads to a decrease in the dominating species population density. Due to the more uniform contribution of particular species to the biomass, $\mathrm{I}_{\mathrm{L}}$ was slightly higher than in the oligohumic lakes (Fig. 3).

The littoral in $\beta$-mesohumic lakes is shallow (0-3 m) and the plant patches are small and scattered. Only 14 species were observed in these lakes. In comparison with the $\alpha$ mesohumic lakes, the percentage of Bryophyta was higher, while the percentage of Cormophyta and Characeae was lower (Table 2). The $\mathrm{H}_{\mathrm{L}}$ index was lower than in the $\alpha$-mesohumic lakes which was related to the reduction in the number of species and the significant decrease in the density of populations of other species. These changes were confirmed by a higher Pielou index than in the $\alpha$-mesohumic lakes (Fig. 3).

Only six species of macrophytes occurred in polyhumic lakes (Table 2). They were widely scattered (Me of frequency $<0.01 \%$ ), did not form multispecies patches and occurred at depths not exceeding $1 \mathrm{~m}$ (Fig. 1, 2). Bryophyta, that tolerated shade, was the main component and it occurred in every lake, while the only Cormophyta observed was Lobelia dortmanna and no Characeae were observed (Table 2). No underwater plants were noted at all in some of the polyhumic lakes. In general, the diversity of vegetation was lower here than in the mesohumic lakes.

The number of species decreased from oligohumic to polyhumic lakes (Fig. 4), and the proportions between parti- 
TABLE 2. Flora of oligo-, $\alpha$-, $\beta$-meso- and polyhumic lakes (1-28).

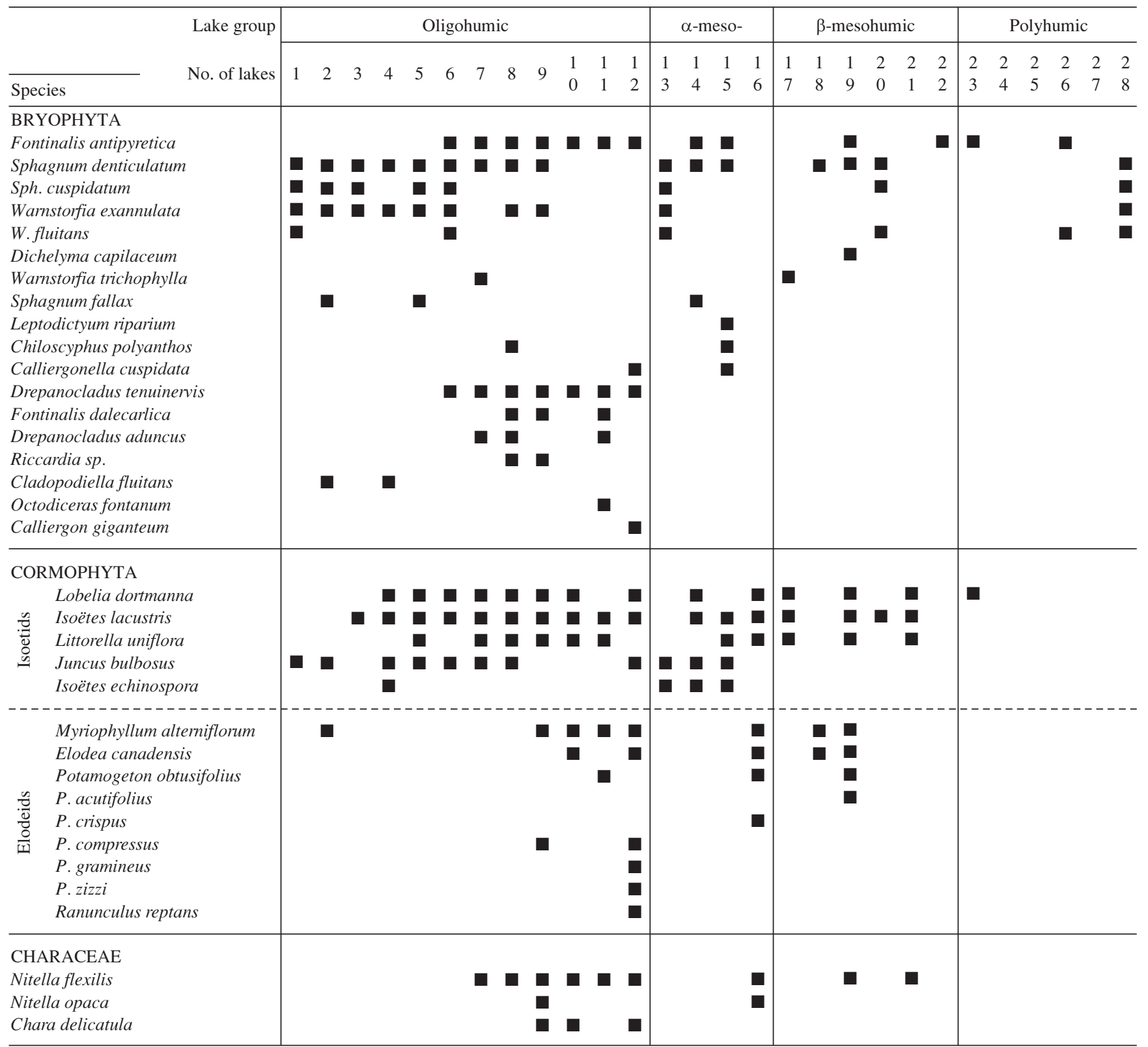

cular species groups also changed. The number of Bryophyta increased, while Cormophyta remained at a similar level up to the $\beta$-mesohumic lakes. The percentage of Characeae in the species composition decreased. The degree of flora dissimilarity in mesohumic and polyhumic lakes was not high (5\%), which meant that the flora of the lakes altered by the impact of DOM input did not have specific features. In the polyhumic lakes species extinction leads to the disappearance of underwater vegetation.

It is a paradox that the $\mathrm{H}_{\mathrm{L}}$ index was the smallest in oligohumic lakes (Fig. 3). This was because of the frequent domination of one species in these lakes and the more uniform contribution of species biomass to the total biomass in mesohumic lakes. Considering the significantly lower number of species and the simplified structure of the patches in mesohumic lakes, it cannot be said that there is greater diversity in them. The Shannon-Weaver index, calculated for large areas, is not a sufficient measure of diversity.

\section{DISCUSSION}

Changes in the structure of vegetation and habitats in the soft water lakes studied were caused by humication which had resulted from the inflow of drainage waters from wetlands. The inflow of large amounts of acidic DOM, which is mainly composed of HS, into lakes caused an increase in water tinge (Fig. 1). This resulted in increased light absorption in the 200-365 $\mathrm{nm}$ range (Frimmel 1994), and light spectrum and water thermal conditions also changed. Humic substances formed colloidal complexes that scattered light (Wilkinson et al. 1997) and limited the illumination of plant habitats. HS in lake waters reacted with water and sediment components thus reducing their availability to plants (Jones et al. 1988; Sunda 1994). These mineral-humic complexes sedimented and altered the chemical composition of the sediments and blocked the transfer of some nutrients (Stewart and Wetzel 1983). Their sedimentation 
also meant that the usually richer existing habitats were covered. The sediments also became gelatinous, more hydrated and dissolved. Each of these aspects was important for the development of plants (e.g. Barko and Smart 1986) since the soil type was a limiting factor. The sedimentation of DOM modified the sediments and limited the illumination of the habitats. When this occurred, the underwater plant habitats shrank and moved towards the shore (Fig. 1, Table 1). Therefore, the transformation of the habitats was caused by the direct impact of DOM and from the indirect impact of their shifting towards the shore. The altered habitats caused the underwater vegetation to regress.

The number of species decreased from oligohumic to polyhumic lakes (Fig. 4), and the proportions between particular species groups also changed. Flora of the lakes altered by the impact of DOM input did not have specific features. The primary process was the reduction in the number of species of all plant groups. Flora reconstruction was not observed and new, invasive species did not appear; this is dissimilar to cases of eutrophication or acidification for which species replacement is one of the stages (Roelofs 1983; Vöge 1992; Riis and Sand-Jensen 1998). The lack of new dominants in the process of humication probably resulted from a very strong and at least partially irreversible alteration in the habitats which became so inhospitable to plants that no species was able to occupy the free space.

MacArthur (1955) formulated the hypothesis that the complexity of the system which results from species diversity determines its stability. This hypothesis has been tested many times by Givnish (1994), Margalef (1994) and Tilman and Downing (1994), among others. Unlike terrestrial vegetation, underwater vegetation is composed of a significantly lower number of species, which, in accordance with this hypothesis, renders it far more susceptible to changes. Since underwater plant communities are often dominated by one or a few species, their resistance to changes strongly depends on the characteristics of the dominant species.

Isoetids dominate in soft water oligohumic lakes and survive in mesohumic lakes thanks to their ability to adapt to lowly productive environments (Aulio 1986; Farmer and Spence 1986). The adaptive characteristics are its rosette growth form and CAM metabolism, which increases the efficiency of carbon utilization in the photosynthesis process (Boston and Adams 1986; Keeley 1998). Other important features include the ability to absorb $\mathrm{CO}_{2}$ from the soil (Spence and Maaberly 1985; Boston et al. 1987), slow growth, a high rate of root mass to shoot mass (Szmeja 1994a) as well as higher gas permeability in roots versus shoots (Sand-Jensen et al. 1982; Boston et al. 1989). However, Isoëtes lacustris, the most common isoetid, does not tolerate lake humication well (Bociąg and Szmeja 2003). When there are high DOM concentrations it can only occur in shallow habitats which are highly disturbed. Due to its slow growth and longevity, it is not adapted to these habitats and is susceptible to wave damage (Szmeja 1994b).

The second dominating group in soft water lakes is Bryophyta. They usually inhabit strongly reduced habitats which are not tolerated by the majority of Cormophyta. Bryophyta usually grow deep as they tolerate shade well (Smith 1982). One of the most common species, Fontinalis antipyretica, is tolerant of a wide range of $\mathrm{pH}$ and conductivity changes (Karttunen and Toivonen 1995), and it also tolerates water which is not very transparent. It can adapt to habitats in humic lakes that are strongly disturbed by waves since it attaches to the bottom, e.g. onto tree roots or stones in the water, etc. This characteristic, in addition to its tolerance of shade, allows this plant to inhabit mesohumic and polyhumic lakes.

In lakes ranging from oligohumic to polyhumic, the gradual elimination of plant patches and the simplification of their structure are visible symptoms of underwater vegetation regression (Fig. 2, 3) which leads to the narrowing of the littoral and the transformation of waste vegetation cover into gradually more scattered patches. As a result, the underwater vegetation becomes increasingly less diverse and covers smaller and smaller areas (Fig. 1, 3, 4). Due to the prevalence of small, scattered, single-species aggregations, vegetation diversity in polyhumic lakes is the lowest. At high DOM concentration (DOC concentrations $>16 \mathrm{mg}$ $\mathrm{C} \mathrm{dm}{ }^{-3}$ ) the species extinction in these lakes leads to the ultimate disappearance of underwater vegetation.

It is impossible to determine the duration of lake humication and the rate of vegetation regression based on the studies conducted. However, it is known that intensive drainage works have been carried out for at least 200 years in northwestern Poland (Schroetter 1802), and that these activities intensified in the second half of the twentieth century. Thus, it can be assumed that the high DOM concentration and the regression of underwater vegetation has been constant for at least several decades. Due to such long-term changes, returning the environment to its original state may be a very slow process, as it is in the case of eutrophication (Lampert and Sommer 1993).

\section{ACKNOWLEDGEMENTS}

I wish to thank Professor Józef Szmeja for his comprehensive assistance during the study and for his critical comments regarding the article, Dr. Krzysztof Banaś and Dr. Krzysztof Gos for their assistance in field and laboratory work and to Jennifer Zielińska for translating the text into English. Funding was provided by grant number 6 PO4 G 09918 from the State Committee for Scientific Research.

\section{LITERATURE CITED}

AIKEN G., MCKINGHT D., WERSHAW R. 1985. Humic substances in soil, sediment and water. Geochemistry, isolation and characterisation. Wiley Interscience, New York.

AULIO K. 1986. CAM-like carbon pathway in submerged aquatic plants. Biol. Pl. 28: 234-236.

BANAŚ K. 2002. Impact of humic substances on Sphagnum denticulatum Bridel habitats. Acta Soc. Bot. Pol. 71: 63-69.

BARKO J.W., SMART R.M. 1986. Sediment-related mechanisms of growth limitation in submersed macrophytes. Ecology 67: 1328-1340.

BOCIĄG K., SZMEJA J. 2001. Degeneration of the vegetation of softwater lakes under the influence of humic substances. Ecol. Pol. 49 (4): 309-328.

BOCIĄG K., SZMEJA J. 2003. The disintegration of populations of underwater plants in soft water lakes enriched with acidic organic matter. In: Third symposium for European Freshwater Sciences, Edinburgh, 13-18 July 2003, Programme 8, Abstracts, pp. 42. 
BOSTON H.L., ADAMS M.S. 1986. The contribution of crassulacean acid metabolism to the annual productivity of two aquatic vascular plants. Oecol. 68: 615-622.

BOSTON H.L., ADAMS M.S., MADSEN J.D. 1989. Photosynthetic strategies and productivity in aquatic systems. Aquat. Bot. 34: 27-57.

BOSTON H.L., ADAMS M.S., PIENKOWSKI T.P. 1987b. Models of the use of root-zone $\mathrm{CO}_{2}$ by selected North American isoetids. Ann. Bot. 60: 495-503.

CLESCERI L.S., GREENBERG A.E., EATON A.D. 1989. Standard methods for examination of water and wastewater. American Public Health Association, Washington, pp. 1-1042.

FRIMMEL F.H. 1994. Photochemical aspects related to humic substances. Environ. Int. 20: 373-386.

GIVNISH T.J. 1994. Does diversity beget stability? Nature 371: 113-114.

GÓRNIAK A. 1996. Substancje humusowe i ich rola w funkcjonowaniu ekosystemów słodkowodnych. Dissertationes Universitatis Varsoviensis, 448: 1-151. (in Polish)

HESSEN D.O., TRANVIK L. 1998. Aquatic humus substances. Ecology and biogeochemistry. Ecol. Stud. 133. Springer Verlag, New York, pp 1-360.

HUSTON A.M. 1996. Biological diversity. The coexistence of species on changing landscapes. Cambridge University Press, Cambridge, pp. 1-681.

JONES R., SALONEN K., DE HAAN H. 1988. Phosphorus transformation in the epilimnion of humic lakes: abiotic interactions between dissolved humic materials and phosphate. Freshwat. Biol. 19: 357-369.

KARTTUNEN K., TOIVONEN H. 1995. Ecology of aquatic bryophyte assemblages in 54 small Finnish lakes and their changes in 30 years. Ann. Bot. Fennici 32: 75-90.

KEELEY J.E. 1998. CAM photosynthesis in submerged aquatic plants. Bot. Rev. 64: 121-175.

KESKITALO J., ELORANTA P. 1999. Limnology of humic waters. Backuys Publishers, Leiden, pp. 1-284.

KRUSKAL W.H., WALLIS W.A. 1952. Use of ranks in one-criterion variance analysis. J. Am. Stat. Ass. 47: 583-621.

LAMPERT W., SOMMER U. 1993. Limnooekologie. Georg Thieme Verlag, Stuttgart, New York, pp. 1-440.

LINDEMAN R.H., MERENDA P.F., GOLD R. 1980. Introduction to bivariate and multivariate analysis. Scott, Foresman \& Co. New York.

MACARTHUR R.H. 1955 Fluctuations of animal populations and a measure of community stability. Ecology 36: 533-536.

MARGALEF R. 1994. Dynamic aspects of diversity. J. Veg. Sci. 5: 451-456.

MOORE T.R. 1987. An assessment of a simple spectrophotometric method for the determination of dissolved organic carbon in freshwaters. New Zeal. J. Mar. Fresh. Res. 21: 585-589

PIELOU E.C. 1966. The measurement of diversity in different types of biological collections. J. Theor. Biol. 13: 131-144.

RIIS T., SAND-JENSEN K. 1998. Development of vegetation and environmental conditions in an oligotrophic Danish lake over 40 years. Freshwat. Biol. 40: 123-134.
ROELOFS J.G.M. 1983. Impact of acidification and eutrophication on macrophyte communities in soft waters in the netherlands. i. field observations. Aquat. Bot. 17: 139-155.

SAND-JENSEN K., PRAHL C., STOKHOLM H. 1982. Oxygen release from roots of submerged aquatic macrophytes. Oikos 38: 349-354.

SCHROETTER F.G. 1796-1802. Historisch-geographischer Atlas des Preussenlandes. Karte von Ostpreussen nebst Preussisch Litthauen und Westpreussen nebst Netzdistrich.

SHANNON C.E., WEAVER W. 1949. The mathematical theory of communication. Urbana Ill, University of Illinois Press, Illinois.

SMITH A.J.E. 1982. Bryophyte ecology. Chapman \& Hall, London.

SPENCE D.H.N., MAABERLY S.C. 1985. Occurrence and ecological importance of $\mathrm{HCO}_{3}{ }^{\oplus}$ use among aquatic higher plants. In: Inorganic carbon uptake by aquatic photosynthetic organism. Lucas W.J., Berry J.A. (eds.). The American Society of Plants Physiologists, Rockville, Maryland, pp. 125-142.

STEWART A.J., WETZEL R.G. 1983. Influence of dissolved humic materials on carbon assimilation and alkaline phosphatase activity in natural algal-bacterial assemblages. Freshwat. Biol. 12: 369-380.

SUNDA W.G. 1994. The influence of nonliving organic matter on the availability and cycling of plant nutrients in seawater. In: Role of nonliving organic matter in the Earth's carbon cycle. Zepp R.G., Sonntag C. (eds.). John Wiley \& Sons, Inc., New York., pp. 191-207.

SZMEJA J. 1994a. An individual's status in populations of isoetid species. Aquat. Bot. 48: 203-224.

SZMEJA J. 1994b. Effect of disturbances and interspecific competition in isoetid populations. Aquat. Bot. 48: 225-238.

SZMEJA J. 2000. Tendencies of changes in the flora and vegetation structure of Pomeranian lakes under the influence of humic substances. In: Mechanisms of anthropogenic changes of plant cover: Jackowiak B., Żukowski W. (eds). Bogucki Wyd. Naukowe, Poznań, pp. 85-98.

SZMEJA J., BAZYDŁO E., URUSKA A. 2001. Role of humic substances in the determination of Sphagnum denticulatum Brid. and Myriophyllum spicatum L. habitat conditions. Pol. J. Ecol. 49: 101-113.

THURMAN E.M. 1985. Organic geochemistry of natural waters. Martinus Nijhoff, Rotterdam.

TILMAN D., DOWNING J.A. 1994. Biodiversity and stability in grasslands. Nature 371: 113-114.

Vöge M. 1992. Tauchuntersuchungen an der submersen Vegetation in 13 Seen Deutschlands unter besonderen Berücksichtigung der Isoetiden-Vegetation. Limnologica 22 (11): 82-96.

WHITTAKER R.H. 1975. Communities and ecosystems. MacMillan, New York.

WHITTAKER R.H. 1967. Gradient analysis of vegetation. Biol. Rev. 42: 207-264.

WILKINSON K.J., NEGRE J.C., BUFFLE J. 1997. Coagulation of colloidal material in surface waters: the role of natural organic matter. J. Contamin. Hydrol. 26: 229-243. 


\section{WPEYW KWAŚNEJ MATERII ORGANICZNEJ Z ODWADNIANYCH TORFOWISK NA RÓŻNORODNOŚĆ ROŚLINNOŚCI PODWODNEJ W JEZIORACH MIĘKKOWODNYCH}

\section{STRESZCZENIE}

Praca dotyczy zmian roślinności podwodnej w jeziorach miękkowodnych pod wpływem zasilania allochtoniczną materią organiczną z odwadnianych torfowisk. Celem pracy jest przetestowanie hipotezy dotyczącej roli DOM w kształtowaniu różnorodności roślinności podwodnej. W jeziorach od oligo- do polihumusowych następują zmiany w siedliskach roślin podwodnych, ich ograniczanie do coraz płytszego litoralu (głębokość dolnej granicy maleje z $12 \mathrm{~m}$ do $1 \mathrm{~m}$ ) i regresja roślinności podwodnej. Następuje stopniowe upraszczanie struktury wewnętrznej płatów roślin, spada wskaźnik Shannona-Weavera (Me 0,04 $\rightarrow$ 0,00). W jeziorach występuje coraz mniej gatunków (Me $9 \rightarrow 2$ ), a roślinność podwodna zajmuje coraz mniejszą powierzchnię. Nie następuje przebudowa flory i nie pojawiają się gatunki inwazyjne.

SŁOWA KLUCZOWE: substancje humusowe, rozpuszczona materia organiczna, roślinność podwodna, różnorodność, wskaźnik Shannon-Weavera. 